\title{
Proposal of non-invasive experimental model to induce scoliosis in rats
}

\author{
Proposta de modelo experimental não-invasivo para indução de escoliose \\ em ratos
}

Carlos A. Silva', Rinaldo R. J. Guirro², Gabriel B. Delfino³, Eder J. Arruda ${ }^{3}$

\begin{abstract}
Background: In the literature, there are several experimental models that induce scoliosis in rats; however, they make use of drugs or invasive interventions to generate a scoliotic curve. Objectives: To design and apply a non-invasive immobilization model to induce scoliosis in rats. Methods: Four-week old male Wistar rats $(85 \pm 3.3 \mathrm{~g})$ were divided into two groups: control (CG) and scoliosis (SG). The animals in the SG were immobilized by two vests (scapular and pelvic) made from polyvinyl chloride (PVC) and externally attached to each other by a retainer that regulated the scoliosis angle for twelve weeks with left convexity. After immobilization, the abdominal, intercostal, paravertebral, and pectoral muscles were collected for chemical and metabolic analyses. Radiographic reports were performed every 30 days over a 16-week period. Results: The model was effective in the induction of scoliosis, even 30 days after immobilization, with a stable angle of $28 \pm 5^{\circ}$. The chemical and metabolic analyses showed a decrease $(p<0.05)$ in the glycogenic reserves and in the relationship between DNA and total protein reserves of all the muscles analyzed in the scoliosis group, being lower $(p<0.05)$ in the convex side. The values for the Homeostatic Model Assessment of Insulin Resistance indicated a resistance condition to insulin $(p<0.05)$ in the scoliosis group $(0.66 \pm 0.03)$, when compared to the control group $(0.81 \pm 0.02)$. Conclusions: The scoliosis curvature remained stable 30 days after immobilization. The chemical and metabolic analyses suggest changes in muscular homeostasis during the induced scoliosis process.
\end{abstract}

Keywords: scoliosis; musculoskeletal; non-invasive model.

\section{Resumo}

Contextualização: Encontram-se na literatura diversos modelos experimentais de indução de escoliose em ratos, porém evidencia-se o uso de drogas ou intervenções invasivas para a geração da curvatura escoliótica. Objetivos: Projetar e aplicar um modelo de imobilização não-invasiva para a indução de escoliose em ratos. Métodos: Ratos Wistar machos com idade inicial de quatro semanas $(85 \pm 3,3 \mathrm{~g})$ foram divididos nos grupos controle (GC) e escoliose (GE). Os animais do GE foram imobilizados por dois cintos (escapular e pélvico) de policloreto de vinila (PVC), interligados externamente por um limitador que regulava o ângulo da escoliose durante 12 semanas, com convexidade à esquerda. Após a imobilização, os músculos abdominais, intercostais, paravertebrais e peitorais bilateralmente foram coletados para as análises químio-metabólicas. Os registros radiológicos foram realizados a cada 30 dias, num total de 16 semanas. Resultados: O modelo foi eficiente e eficaz na indução da escoliose, mesmo após 30 dias da desmobilização, mantendo um ângulo estável de $28 \pm 5$ graus. Quanto às análises químio-metabólicas, observou-se diminuição $(p<0,05)$ nas reservas glicogênicas e na relação proteína total/DNA de todos os músculos analisados do GE, sendo menores $(p<0,05)$ no lado da convexidade. Os valores do HOMA-IR indicaram um quadro de resistência à insulina $(p<0,05)$ no $G E(0,66 \pm 0,03)$ quando comparado ao $G C(0,81 \pm 0,02)$. Conclusões: $A$ curvatura escoliótica manteve-se estável após 30 dias da desmobilização, e as alterações químio-metabólicas sugeriram a ocorrência de modificações na homeostasia muscular durante o processo indutor da escoliose.

Palavras-chave: escoliose; musculoesquelético; modelo não-invasivo.

Received: 12/13/2011 - Revised: 12/19/2011 - Accepted: 12/21/2011

${ }^{1}$ Master's Degree Program in Physical Therapy, Universidade Metodista de Piracicaba (UNIMEP), Piracicaba, SP, Brazil

${ }^{2}$ Department of Biomechanics, Medicine, and Rehabilitation of the Locomotor System, Faculdade de Medicina de Ribeirão Preto, Universidade de São Paulo (USP), Ribeirão Preto, SP, Brazil ${ }^{3}$ Undergraduate Program in Physical Therapy, UNIMEP, Piracicaba, SP, Brazil

Correspondence to: Rinaldo Roberto de Jesus Guirro, Faculdade de Medicina de Ribeiro Preto - USP, Departamento de Biomecânica, Medicina e Reabilitação do Aparelho Locomotor, Av. Bandeirantes, 3900, Monte Alegre, CEP 14049-900, Ribeirão Preto, SP, Brazil, e-mail: rguirro@fmrp.usp.br 


\section{Introduction $: \because$.}

Anatomic alterations of the spine have been investigated in clinical and experimental studies not only to create new forms of treatment, but also to elucidate the etiology and the effects that these alterations can have on the body. In this context, researchers have been developing experimental models to promote scoliosis in animals.

For several decades, these models have been developed and many are currently in use, but they are all invasive. Some of them are: the administration of intraperitoneal betaaminopropionitrile to alter the vertebral ligaments ${ }^{1}$; alterations to the intervertebral cartilage of rats $^{2}$; osteolathyrism with carbazide ${ }^{3}$; mechanical separation of the vertebrae of rats to limit movement ${ }^{4}$; suture of musculature next to vertebrae to limit movement ${ }^{5}$; increase in flexibility after chymopapain injection ${ }^{6}$; growth modulation after fusion of vertebrae ${ }^{7}$; model to correct scoliosis with transfixation pins in the spine ${ }^{8}$; transfixation pins to maintain spinal position $^{9}$; maintenance system applied to the intervertebral discs interfering in the scoliotic curve $e^{10}$, and more recently, an experimental model to induce scoliosis based on the use of steel wires ${ }^{11}$. Obsolescence was observed along the years regarding the development of new methodologies to induce experimental scoliosis in animals. In more recent articles, old and obsolete induction methods have been reported.

It has been demonstrated that scoliosis is not exclusive to bipedalism ${ }^{12}$. In this context, our research group strived to develop a methodology that would be different from the existing ones. Some aspects were considered: time, risk of losing the animals, simple planning, and especially no surgery so that the surrounding tissue structures in the spine would not be affected and, therefore, not interfere with the parameters that could be analyzed for the development and treatment of scoliosis. Thus, the main objective of this study was to design and apply a non-invasive method to induce scoliosis in rats.

\section{Methods $: \because 8$}

\section{Animals}

Twenty-four male Wistar rats were divided into two groups: control ( $\mathrm{CG}, \mathrm{n}=8$ ) and scoliosis ( $\mathrm{SG}, \mathrm{n}=16)$, with initial weight of $85 \pm 3.3 \mathrm{~g}$. The $\mathrm{SG}$ was subdivided into two other groups: scoliosis x-ray and chemical-metabolic. The animals were given ordinary feed as well as water ad libitum and submitted to bioterium facilities, with a 12-hour lightdark cycle. This study was approved by the Ethics Committee for Animal Experimentation at Universidade Federal de
São Carlos (UFSCar), São Carlos, SP, Brazil, under protocol number 024/2006.

\section{Orthosis design}

The orthosis comprised two vests made from polyvinyl chloride (PVC), 0.50mm thick, in nine different sizes to allow growth. The sequence and measures are shown in Figure 1. A scoliosis angle of $40^{\circ}$ was delimited by the fixation of two plastic holders, each one fixed to one of the vests connected by a metallic wire. To avoid cutaneous lesions, the edges of the vest were covered with rubber adhesive and synthetic resin (Figure 2). The vests were made to protect against any cutaneous lesions as well as to allow breathing and moving.

\section{Immobilization}

The immobilization period began after the weaning stage (28 days of age) and lasted 12 weeks. The PVC vest was adjusted to develop left convexity scoliosis. They were changed every 7 days and maintained for a period of 12 weeks. Afterwards, the animals were followed up for another 4 weeks (immobilizationfree period).

\section{Radiological analysis}

The animals were x-rayed after $24 \mathrm{~h}$ of immobilization and every 4 weeks. The digital imaging was analyzed with the software ALCimagem to measure the scoliosis angle. The following parameters were used: Posterior-Anterior incidence (PA), $50 \mathrm{kVp}$, 6-pulse exposure time, focal distance/ chassis $75 \mathrm{~cm}$, and film for $20.2 \times 25.3 \mathrm{~cm}$ x-ray (Kodak $\left.{ }^{\circledR}\right)$. The animals were previously anesthetized with sodium pentobarbital (40 mg/Kg, i.p.).

\section{Sampling}

The animals were anesthetized with sodium pentobarbital (40 mg/Kg, i.p.) to collect abdominal, intercostal, paravertebral, and pectoral muscles bilaterally.

\section{Determining the muscular glycogen}

The muscle samples were digested in $\mathrm{KOH} 30 \%$ hot, and the glycogen was precipitated from the passage of hot ethanol. The sample was centrifuged at $3000 \mathrm{rpm}$, and the glycogen was subjected to acid hydrolysis in the presence of phenol ${ }^{13}$. Values were expressed in $\mathrm{mg} / 100 \mathrm{mg}$ wet weight. 


\section{Total protein concentration}

A PROTAL kit (Laborlab, cat. n 03800) was used. Its principle is based on the fact that substances containing two or more peptide bonds form a violet-colored complex in an alkaline solution when diluted with copper sulfate. Values are expressed in g/dL.

\section{Muscular DNA concentration}

The diphenylamine method was used. First, the tissue homogenate was submitted to a diphenylamine solution then to a spectrophotometer reading, with $595 \mathrm{~nm}$ wavelength ${ }^{14}$.
A

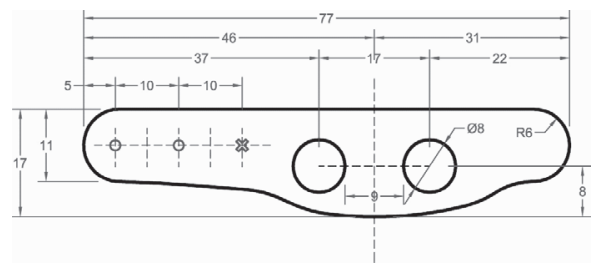

B

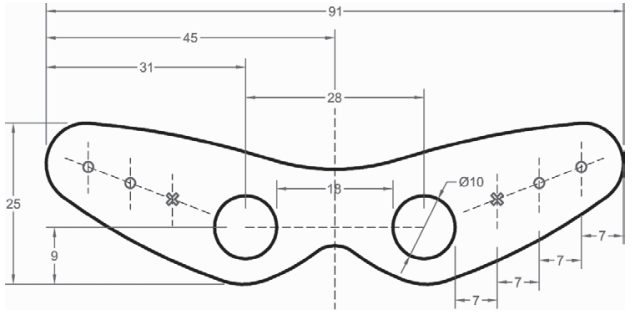

C

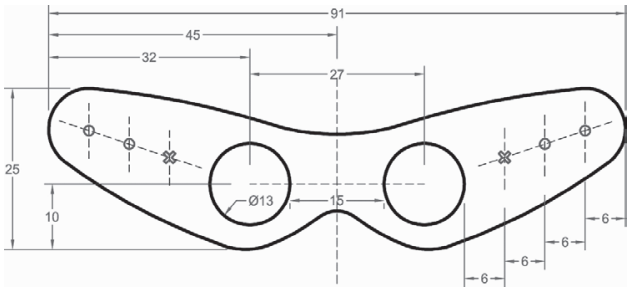

D
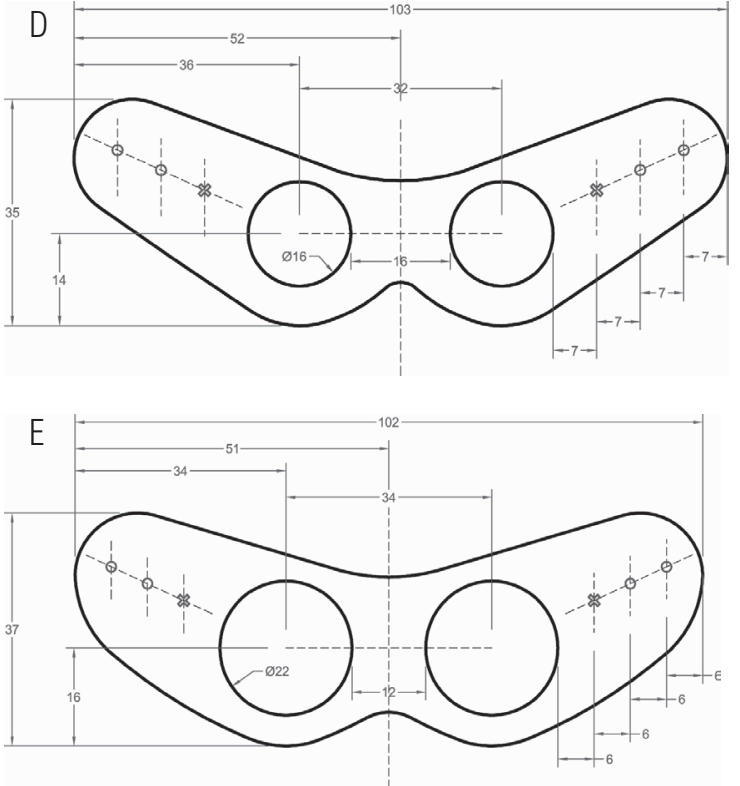

F

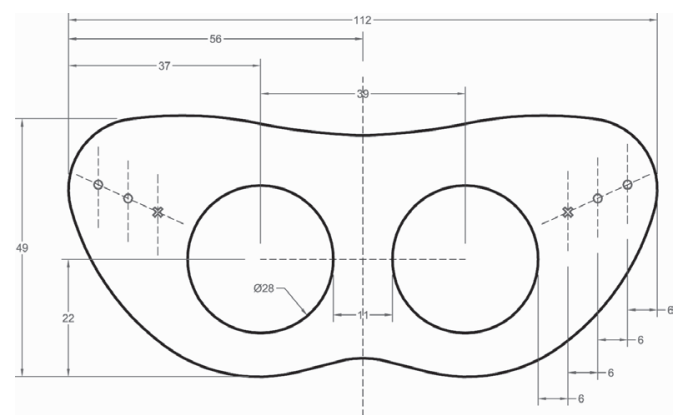

G

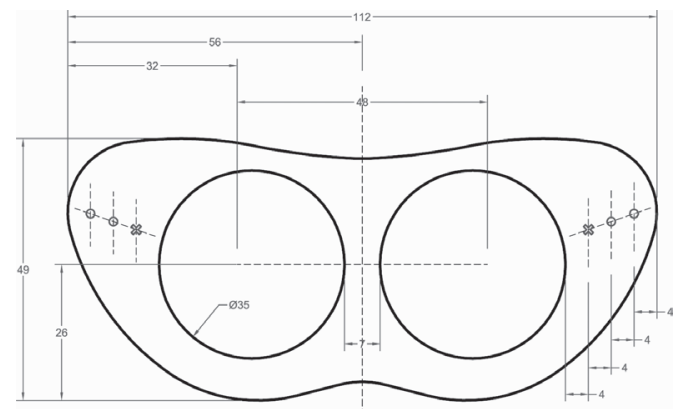

H
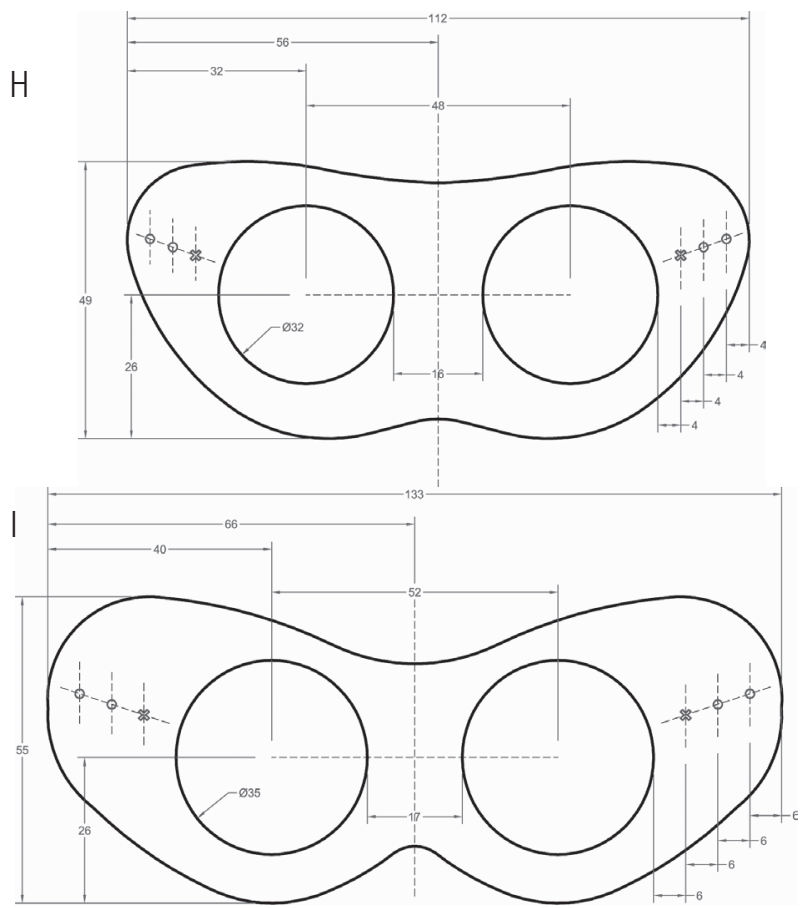

A-scapular $1^{\text {st }}$ week; B-pelvic $1^{\text {st }}$ week and scapular in the $2^{\text {nd }}$ week; C-pelvic $2^{\text {nd }}$ week and scapular in the $3^{\text {rd }}$ week; D-pelvic $3^{\text {rd }}$ week and scapular $4^{\text {th }}$ week; E-pelvic $4^{\text {th }}$ week and scapular $5^{\text {th }}$ and $6^{\text {th }}$ week; F-pelvic $5^{\text {th }}$ and $6^{\text {th }}$ week and scapular $7^{\text {th }}, 8^{\text {th }}, 9^{\text {th }}$ and $10^{\text {th }}$ week, G-pelvic $7^{\text {th }}$ and $8^{\text {th }}$ week; H-pelvic $9^{\text {th }}$ and $10^{\text {th }}$ week and scapular $11^{\text {th }}, 12^{\text {th }}$ week; I-pelvic $11^{\text {th }}$ and $12^{\text {th }}$ week. The " $x$ " in each vest represents the fixation point of the pin, and the circles represent the passage point of the plastic retainer to fasten the vest.

Figure 1. Orthosis models attached to the scapular or pelvic vests used for immobilization. 


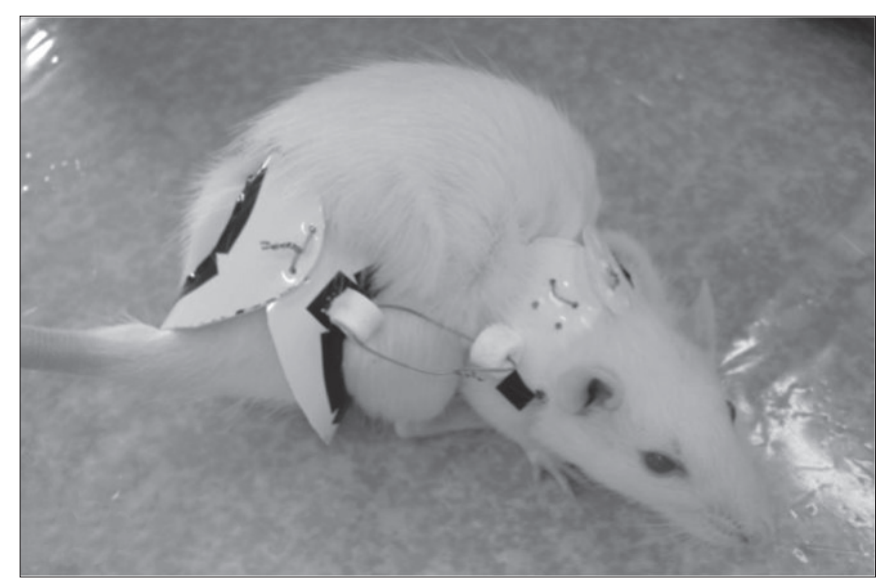

Figure 2. PVC orthosis in the shape of a vest.

\section{Plasma insulin concentration}

The plasma insulin was measured by radioimmunoassay. This technique consists in the transference of an unknown amount of plasma to the tube containing anti-insulin antibodies and insulin marked with a tracer (iodine-125) ${ }^{15}$.

\section{Statistical analysis}

The Kolmogorov-Smirnov test was used, followed by ANOVA and the Tukey test. For all measurements, the level of significance was set at $5 \%$.

\section{Results $: \therefore$.}

The radiographic imaging taken every 4 weeks showed the development of scoliosis (Figure 3A). The animals in the CG did not show any deviation, unlike the SG, which developed a "C" curve with an average angle of $40^{\circ}$ while using vest. It remained stable at $28 \pm 5^{\circ}$ for 4 weeks after immobilization (Figure $3 \mathrm{~B}$ ).

During immobilization, the animal's body weight was monitored for 12 weeks. It was observed that the immobilized animals had an average weight $29.4 \pm 2.7 \%$ lower than the animals in the CG (Figure 4). It is important to consider that the lower weight may be related to the food intake, which was $25 \%$ lower than that of the CG $(60 \pm 5.0 \mathrm{~g} /$ day for the $\mathrm{CG}$ vs. $45 \pm 3.0 \mathrm{~g} /$ day for the $\mathrm{SG})$.

When considering the weight of the vest, a progressive increase was observed with the animals' growth. However, when considering the relationship between the total weight of the orthosis and the animals' body weight, the mean was $4.3 \pm 0.2 \%$.

When comparing the PT/DNA relationship between the CG and the SG, which showed alterations in the number of myofibrils, there was a significant reduction in the convex side involving $11 \%$ of the right abdominal muscle, $16 \%$ of the left
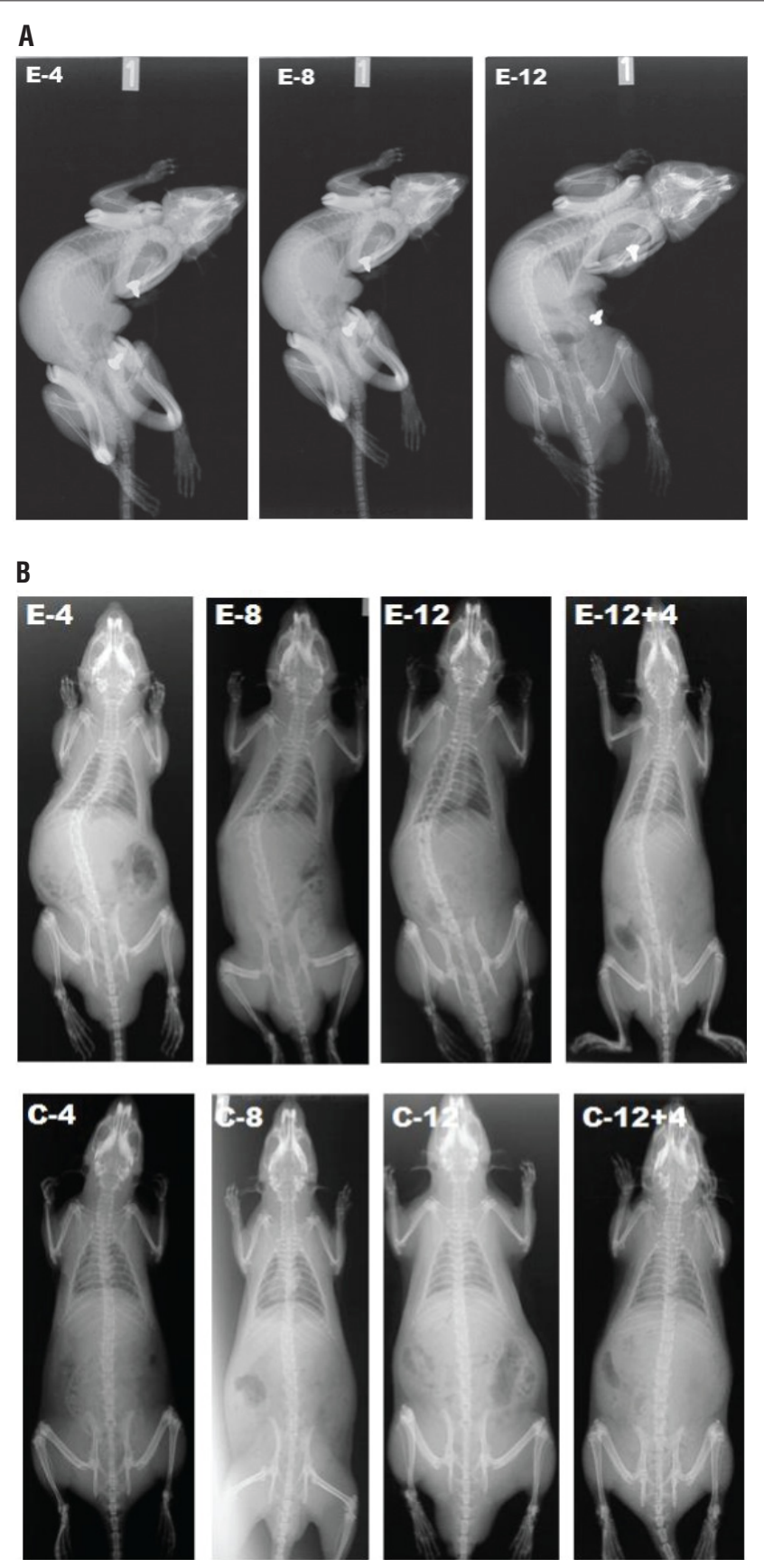

Figure 3. Radiograph of A) scoliotic animals using the PVC vest, B) animals from the scoliotic group (SG) and control group (CG) after removing the PVC vest. Images taken on the $4^{\text {th }}, 8^{\text {th }}$, and $12^{\text {th }}$ week of immobilization and 4 weeks after immobilization (12+4).

abdominal, $14 \%$ of the right intercostal, $33 \%$ of the left intercostal, $8.5 \%$ of the right pectoral, $18 \%$ of the left pectoral, $9 \%$ of the right paravertebral, and $20 \%$ in the left paravertebral muscle (Table 1). When comparing the convex and the concave sides, in the same table, there was no difference in the CG. In the SG, however, the values were lower in the convex side involving $10 \%, 25 \%, 13 \%$, and $16 \%$ of the abdominal, intercostal, pectoral, and paravertebral, respectively. 
The values of glycogen reserves showed that the muscles of the scoliotic animals showed reduction in the right (41\%) and left intercostal (67\%); right (44\%) and left pectoral (59\%); abdominal right (45\%) and left abdominal (51\%), and right and left paravertebral muscles (64\%), when compared with the animals in the CG. When comparing the muscles in the concave side with the convex side, the lower glycogen reserve was $40 \%$ lower in the intercostal muscle, $28 \%$ in the pectoral, $13 \%$ in the abdominal, and $20 \%$ in the paravertebral (Table 1).

For a complete chemical and metabolic analysis, the Homeostatic Model Assessment method was used to estimate the insulin resistance function (HOMA-IR) with values of $0.81 \pm 0.02$ in the $C G$, and $0.66 \pm 0.03$ in the $S G$, with a reduction of $18 \%$.

\section{Discussion $: \because$.}

The greatest advantage of this non-invasive scoliosis model was that it allowed the development of scoliosis in animals without the use of any type of surgery or medication as these interventions can affect not only the spine but also the adjacent tissues. Another important aspect is the preservation of all the tissues/structures that can be analyzed after immobilization or even after therapeutic interventions aimed to minimize scoliosis. Additionally, this model can be easily prepared to allow its application on a large number of animals in a short period of time and with low costs, as achieved in the present study.

Our model differed from the ones found in the literature due to its non-invasive approach. An example of an invasive model in rats consisted in a suture of the inferior angle of the scapula to the pelvis ipsilaterally next to the base of the tail. The author found that the ideal time for the induction of a permanent scoliotic curvature would be 8 weeks. He emphasized that the aim of his study was to evaluate the scoliosis during the period between 1 to 12 weeks after surgery. However, he verified that in 6 weeks, the curvature was already permanent ${ }^{16}$.

In search for an experimental model, we also found those that differed from the invasive (surgical) procedure. However, their applicability focused on the alteration of the biochemical and endocrine aspects of the animals through the administration of mutagenic substances during their development stage, osteolathyrism, and removal of secreting organs such as the pineal gland ${ }^{17}$.

Another aspect related to the experimental scoliosis lies in the fact that among the animals used in studies, i.e. chickens, goats, rabbits, and rats, the latter had the lowest number of papers published, making it harder to obtain information for comparisons between the induction models in the same animal model ${ }^{7,18,19}$.

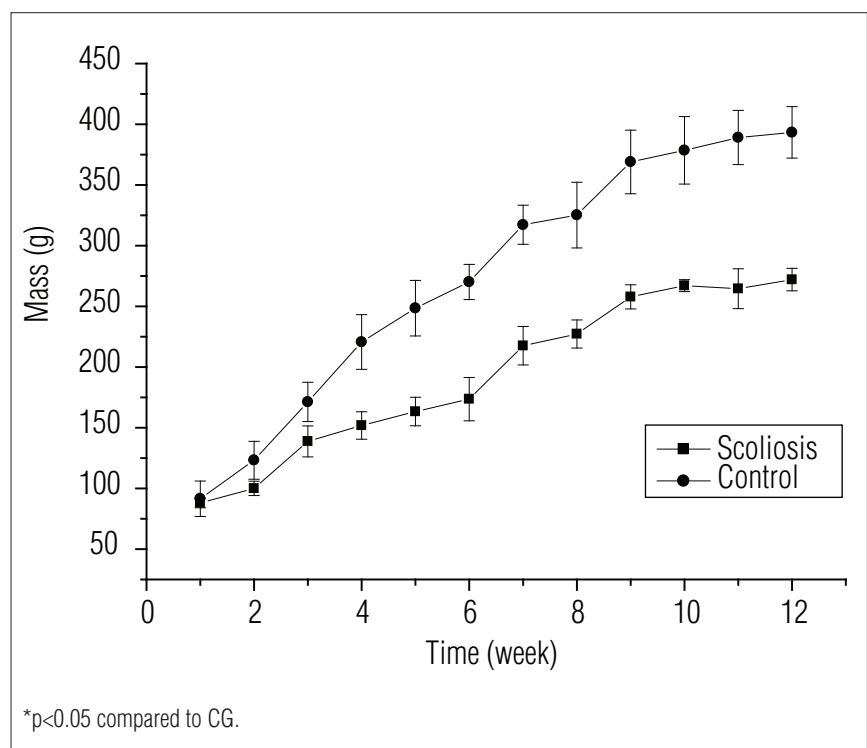

Figure 4. Mean $\pm S D$ of mass $(\mathrm{g})$ of the rats in the control group (CG) and scoliosis group (SG) between the $1^{\text {st }}$ and $12^{\text {th }}$ week, $n=8$.

Table 1. DNA/total protein relationship and muscle glycogen (mg/100mg) after 12 weeks of immobilization of the different muscles of rats in the control group and scoliosis group. The left side $(\mathrm{L})$ is convex, and the right side $(\mathrm{R})$ is concave. Values refer to mean \pm epm, $n=6$.

\begin{tabular}{lcccc}
\hline \multirow{2}{*}{ Muscle } & \multicolumn{2}{c}{ DNA/Total Protein } & \multicolumn{2}{c}{ Glycogen } \\
& Control & Scoliosis & Control & Scoliosis \\
Group & Group & Group & Group \\
\hline Abdominal R & $3.49 \pm 0.02$ & $3.10 \pm 0.02^{*}$ & $0.58 \pm 0.04$ & $0.32 \pm 0.05^{\star}$ \\
\hline Abdominal L & $3.34 \pm 0.04$ & $2.80 \pm 0.03^{\star *}$ & $0.57 \pm 0.01$ & $0.28 \pm 0.01^{\star *}$ \\
\hline Intercostal R & $3.55 \pm 0.02$ & $3.04 \pm 0.03^{*}$ & $0.51 \pm 0.04$ & $0.30 \pm 0.005^{*}$ \\
\hline Intercostal L & $3.40 \pm 0.03$ & $2.27 \pm 0.02^{\star *}$ & $0.55 \pm 0.005$ & $0.18 \pm 0.009^{\star *}$ \\
\hline Pectoral R & $3.28 \pm 0.03$ & $3.00 \pm 0.03^{*}$ & $0.50 \pm 0.06$ & $0.28 \pm 0.009^{*}$ \\
\hline Pectoral L & $3.19 \pm 0.02$ & $2.60 \pm 0.03^{\star *}$ & $0.49 \pm 0.03$ & $0.20 \pm 0.01^{\star *}$ \\
\hline Paravertebral R & $3.41 \pm 0.03$ & $3.12 \pm 0.03^{*}$ & $0.55 \pm 0.06$ & $0.20 \pm 0.009^{*}$ \\
\hline Paravertebral L & $3.29 \pm 0.01$ & $2.62 \pm 0.03^{\star *}$ & $0.44 \pm 0.02$ & $0.16 \pm 0.008^{\star *}$ \\
\hline
\end{tabular}

${ }^{*} p<0.05$ compared to control group. ${ }^{*} p<0.05$ compared to the right side.

Among the most invasive methodologies, one that stands out involved the removal of the hind limbs and the tail of the animal so that it could assume the biped position ${ }^{17}$. However, the group where the animals were submitted to associated surgery pinealectomy had scoliosis, showing a relation with melatonin deficiency in the development of idiopathic scoliosis.

In order to verify the effectiveness of the proposed model, the animals were evaluated during the four weeks after immobilization, and the scoliotic curve did not return to the level considered normal, even after the vests were removed. To minimize the possible influence of space in the containment box in relation to the animals' growth, four rats were placed in each box ${ }^{20}$. The reduction in body weight may be due to the functional limitation exerted by the vest, considering that no alterations were observed in response to the central nervous 
system, especially in the hypothalamus with behavior reflexes ${ }^{21}$. The weight of the vest could also be considered important; however, the percentage represented by weight of the vest compared to the animal's weight suggested that this parameter was not relevant.

The evaluation of the DNA/total protein relationship observed in the scoliosis group could be represented by the action of the catabolic systems that follow disuse, suggesting two patterns: reduction in the synthesis process and prevalence of proteolysis-inducing factors.

It should be considered that the events that could have taken part in the muscle alterations are multi-factorial; therefore, further studies are necessary to provide a better understanding of this interface. The muscle glycogen content is considered an important energy reserve and, when submitted to alterations, it can affect performance, i.e. it can improve resistance when elevated and, when depleted, it can participate in processes associated with fatigue and muscular hypertrophy 22,23 .

In the present study, there was a significant reduction in the glycogen muscle reserves in scoliotic animals. In the literature, it has been reported that paravertebral muscles had a predominance of type I (red) fibers that were predominantly oxidative $^{24}$. This study emphasized that the low glycogen reserves were involved in the chemical and metabolic balance of the fibers and could be linked to several factors that can affect the homeostasis of the processes that regulate the formation of metabolized substrate reserves. Another aspect to consider is that the proposed model creates a process of muscle disuse similar to long periods in bed, limb fixation, microgravity, or the use of orthoses. These factors trigger a catabolic state in the skeletal muscles ${ }^{25-27}$.

With regard to the endocrine profile, it is known that insulin is extremely important among the hormones involved in the regulation of carbohydrate metabolism and the modulation of the skeletal muscles ${ }^{28}$.

Many authors have been studying the mechanics triggered in the muscle in disuse and have verified a reduction in insulin signal transduction, which suggests deficit in the insulin receptor activation and in the enzymes activated from it, including phosphorylation of IRS-1 (insulin receptor substrate-1) and P13-K activation, decrease in the amount of glucose transporter protein (GLUT4), and insulin resistance ${ }^{22}$. Our results showed a significant reduction in glycogen reserves in the paravertebral muscles of scoliotic animals, simulating the disuse condition created by other immobilization methods.

Finally, due to the situation where homeostasis was disturbed, the HOMA-IR was evaluated; it was verified that in the SG the index was reduced, revealing a disturbance in insulin sensitivity.

It is worth mentioning that the physiological relationships between the phenomena linked to insulin sensitivity and the scoliosis induction process still need further investigation. However, this was a pioneer study as it demonstrated chemical and metabolic alterations in the non-invasive scoliosis induction model. These alterations were part of the mechanisms used concomitantly for the development of scoliosis and reflected an anatomical and functional interface that requires further investigation to provide new perspectives on the histophysiological analyses, as well as the applicability and effectiveness of therapeutic methods commonly used for the rehabilitation process of scoliosis.

\section{Conclusion $: \because$.}

Considering the experimental aspects of this study, it can be concluded that:

- The PVC vest was effective in the development of scoliotic curvature during the three-month immobilization period and one-month period free from immobilization, maintaining a stable curvature;

- Some metabolic alterations occurred in the skeletal muscles as observed in the analyses of the glycogen reserves, in the total protein/DNA relationship affected by a negative protein balance, and in the sensitivity to insulin, suggesting that the changes in muscle homeostasis followed the scoliosis-induced process.

\section{Acknowledgments $\because \because$.}

To Conselho Nacional de Desenvolvimento Científico e Tecnológico (CNPq), Brasilia, DF, Brazil, (Institutional Program of Grants for Scientific Initiation); Research Foundation UNIMEP and Fundação de Amparo à Pesquisa do Estado de São Paulo (FAPESP), São Paulo, SP, Brazil (São Paulo Research Foundation), Process 2006/60651-1. 


\section{References $: \because$.}

1. Nogami H, Terashima Y, Tamaki K, Oohira A. Congenital kyphoscoliosis and spinal cord lesion produced in the rat by beta-aminopropionitrile. Teratology. 1977;16(3):351-7.

2. Beguiristain JL, Salis J, Oriaifo A, Canãdell J. Experimental scoliosis by epiphysiodesis in pigs. International Orthopaedics. 1990;3(4):317-21.

3. Tanaka H, Kimura Y, Ujino Y. The experimental study of scoliosis in bipedal rat in lathyrism. Arch Orthop Trauma Surg. 1982;101(1):1-27.

4. Dabney KW, Salzman SK, Wakabayashi T, Sarwark JF, Gao GX, Beckman AL, et al. Experimental scoliosis in the rat. II. Biomechanical analysis of the forces during Harrington distraction. Spine (Phila Pa 1976). 1988;13(5):472-7.

5. Kasuga K. Experimental scoliosis in the rat spine induced by binding the spinous processes. Nihon Seikeigeka Gakkai Zasshi. 1994;68(9):789-807.

6. Lu DS, Luk KD, Lu WW, Cheung KM, Leong JC. Spinal flexibility increase after chymopapain injection is dose dependent: a possible alternative to anterior release in scoliosis. Spine (Phila Pa 1976). 2004;29(2):123-8.

7. Braun JT, Akyuz E, Ogilvie JW. The use of animal models in fusionless scoliosis investigations. Spine (Phila Pa 1976). 2005;30(17 Suppl):S35-45.

8. Rooney GE, Vaishya S, Ameenuddin S, Currier BL, Schiefer TK, Knight A, et al. Rigid fixation of the spinal column improves scaffold alignment and prevents scoliosis in the transected rat spinal cord. Spine (Phila Pa 1976). 2008;33(24):914-24.

9. Stokes $I A, M c B r i d e ~ C A$, Aronsson DD. Intervertebral disc changes in an animal model representing altered mechanics in scoliosis. Stud Health Technol Inform. 2008;140:273-7.

10. Schmid EC, Aubin CE, Moreau AE, Sarwark J, Parent S. A novel fusionless vertebral physeal device inducing spinal growth modulation for the correction of spinal deformities. Eur Spine J. 2008;17(10):1329-35.

11. Schwab F, Patel A, Lafage V, Farcy JP. A porcine model for progressive thoracic scoliosis. Spine (Phila Pa 1976). 2009;34(11):E397-404.

12. Gorman KF, Breden F. Idiopathic-type scoliosis is not exclusive to bipedalism. Med Hypotheses. 2009;72(3):348-52.

13. Lo S, Russell JC, Taylor AW. Determination of glycogen in small tissue samples. J Apll Physiol. 1970;28(2):234-6.

14. Giles KW, Myers A. An improved diphenylamine method for the estimation of deoxyribonucleic acid. Nature. 1965;206:93-9.
15. Scott AM, Atwater I, Rojas E. A method for the simultaneous measurement of insulin release and B cell membrane potential in single mouse islets of Langerhans. Diabetologia 1981;21(5):470-5.

16. SarwarkJF, Dabney KW, Salzman SK, Wakabayashi T, Kitadai HK, Beauchamp JT, etal. Experimental scoliosis in the rat. I. Methodology, anatomic features and neurologic characterization. Spine (Phila Pa 1976). 1988;13(5):466-71.

17. Machida M, Saito M, Dubousset J, Yamada T, Kimura J, Shibasaki K. Pathological mechanism of idiopathic scoliosis: experimental scoliosis in pinealectomized rats. Eur Spine J. 2005;14(9):843-8.

18. Machida M, Murai I, Miyashida I, Dubousset J, Yamada T, Kimura J. Pathogenesis of idiopathic scoliosis. Experimental study in rats. Spine (Phila Pa 1976). 1999;24(19):1985-9.

19. Joe T. [Studies of experimental scoliosis produced by electric stimulation. With special reference to the histochemical properties of the muscle]. Nihon Ika Daigaku Zasshi. 1990;57(5):416-26

20. Genaro G, Schmidek WR, Franci CR. Social condition affects hormone secretion and exploratory behavior in rats. Braz J Med Biol Res. 2004; 37:833-40.

21. Silva CA, Guirro RRJ, Fonseca V, Arruda EJ, Grassi DO. Assessment of rat behavior with induced scoliosis by polyvinyl chloride vests. Journal Chinese Clinical Medicine. 2008;31:621-6.

22. Hirose $M$, Kaneki M, Sugita $H$, Yasuhara $S$, Martyn JA. Immobilization depresses insulin signaling in skeletal muscle. Am J Physiol Endocrinol Metab. 2000;279(6):1235-41.

23. Coderre L, Vallega GA, Pilch PF, Chipkin SR. Regulation of glycogen concentration and glycogen synthase activity in skeletal muscle of insulin-resistant rats. Arch Biochem Biophys. 2007;464(1)144-50.

24. Delp MD, Duan C. Composition and size of type I, IIA, IID/X and IIB fibers and citrate synthase activity of rat muscle. J Appl Physiol. 1996;80(1):261-70.

25. Stein TP, Schulter MD, Boden G. Development of insulin resistance by astronauts during spaceflight. Aviat Space Environ Med. 1994;65(12):1091-6.

26. Ferrando AA, Lane HW, Stuart CA, Davis-Street J, Wolfe RR. Prolonged bed rest decreases skeletal muscle and whole body protein synthesis. Am J Physiol. 1996;270(4 Pt 1):E627-33.

27. Lima SC, Caierão QM, Durigan JQ, Schwarzenbeck A, Silva CA, Minamoto VB, et al. Shortterm immobilization causes morphometric and mechanical alterations in rat muscles. Rev Bras Fisioter. 2007;11(4):297-302.

28. Sesti G. Pathophysiology of insulin resistance. Best Pract Res Clin Endocrinol Metab 2006;20(4):665-79. 